\title{
Pengaruh Pengungkapan Corporate Social Responsibility, Persistensi Laba dan Pertumbuhan Laba Terhadap Manajemen Laba pada Perusahaan yang Terdaftar di Jakarta Islamic Index
}

\author{
Nawang Kalbuana ${ }^{1)}$, Satiti Utami ${ }^{2)}$, Aditya Pratama ${ }^{3)}$ \\ ${ }_{1,2}$ Politeknik Penerbangan Indonesia Curug \\ ${ }^{3}$ Institut Teknologi dan Bisnis Ahmad Dahlan -Jakarta \\ *Email korespondensi: nawang.kalbuana@ppicurug.ac.id, satiti.utami@ppicurug.ac.id
}

\begin{abstract}
Earning management is often done by the company, but until now very rarely research conducted especially on companies that apply the principle of Islam so that the whole company impressed will apply it. The purpose of this research is to prove and analyze the influence of corporate social responsibility disclosure, profit-statement, and profit growth on earning management, especially in companies listed in the Jakarta Islamic Index (JII) during 2015-2018. Earning management uses Jones ' modification Model (1995), independent variables are researched, among others, corporate social responsibility disclosures, profit persistence, and profit growth. Samples were selected by the Purposive sampling method and were conducted hypothesis testing using multiple linear regression analysis methods. Based on the results of research that has been done proved that in the company applying the ethical principles of Islam shows that the disclosure of corporate responsibility and persistence of profit proved to have no influence on earning management, but profit growth has a significant positive influence on earning management.
\end{abstract}

Keywords: corporate social responsibility disclosure, profit-statement, profit growth, earnings management

Saran Sitasi: Kalbuana, N., Utami, S., \& Pratama, A. (2020). Pengaruh Pengungkapan Corporate Social Responsibility, Persistensi Laba dan Pertumbuhan Laba Terhadap Manajemen Laba Pada Perusahaan yang Terdaftar di Jakarta Islamic Index. Jurnal Ilmiah Ekonomi Islam, 6(02), 350-358. doi:http://dx.doi.org/10.29040/jiei.v6i2.1107

DOI: $\underline{\text { http://dx.doi.org/10.29040/jiei.v6i2.1107 }}$

\section{PENDAHULUAN}

\subsection{Latar Belakang}

Laba adalah selisih dari pendapatan dan beban perusahaan sebagai salah satu tolak ukur perusahaan dalam menilai kinerja perusahaan tersebut, (Ghozali.\&.Chariri,2007). Management laba adalah merupakan suatu campur tangan manajerial untuk memanipulasi laporan keuangan yang bertujuan agar dapat memperlihatkan kondisi keuangan perusahaan tersebut dalam laporan tersebut yang terkesan lebih baik, (Mulford,2002). Pelaporan kinerja keuangan dalam laporan keuangan tidak lagi memberikan informasi yang akurat akibat dari tingka ekspentifnya perusahaan dalam hal melakukan tindakan manajemen laba, (Chih, et. AL, 2008). Pada kondisi tersebut akan mengakibatkan kesalahan oleh pengguna laporan keuangan dalam hal mengambil keputusan yang tepat karena diakibatkan oleh suatu tindakan manajerial untuk dapat melakaukan manajemen laba untuk terkesan lebih baik padahal tidak seperi demikian. Yang dimaksud dengan CSR Corporate Social Responsibility) ialah merupakan suatu kewajiban \& komitmen dalam organisasi bisnis untuk dapat memberikan kontribusi terhadap pengembangan ekonomi serta bertindak etis dari suatu komunitas setempat/ masyarakat luas, dan bersaman dengan peningkatan taraf hidup pekerja beserta keluarganya, Wibisono (2007:7). Isu mengenai tanggung jawab sosial perusahaan atau CSR (Corporate Social Responsibility) semakin menjadi sorotan penting dalam beberapa tahun terakhir karena konsep CSR merupakan inti dari etika bisnis perusahaan. Tujuan utama CSR adalah menjadikan perusahaan bukan hanya pada konsep single-bottomline (SBL) dalam suatu catatan keuangan perusahaan, tetapi juga pada konsep triple-bottom-line (TBL) yang mencakup aspek keuangan, kehidupan sosial serta 
lingkungan (Kalbuana, Sutadipraja, Purwanti, \& Santoso, 2019).

Sebagai bentuk informasi pertanggungjawaban atas kegiatan CSR dan manajemen laba yaitu diperlukannya pelaporan praktik CSR oleh perusahaan. Dapat menurunkan asimetri informasi apabila peningkatannya infomasi dalam pengungkapan laporan keuangan, peningkatan tersebut akan mengakibatkan fleksibiitas manajer dalam melakaukan berkurangnya suatu manajemen laba yaitu dikarenakan berkurang-nya juga asimetri informasi antara manajemen laba terhadap stakeholders.

Schipperand Vincent (2003), bahwa sebagai dasar pengambilan keputusan yaitu laba yang digunakan oleh investor dan kreditor untuk pembuatan keputusan kontrak, keputusan investasi \& pembuat sandar. Berdasarkan pada persistensi laba yang rendah keputusan melakukan kontrak akan mengakibatkan terjadinya transfer kesejahteraan yang tidak diinginkan oleh semua pihak. Contohnya adalah yang mengakibatkan kompensasi yang berlebihan kepada manajer yaitu karena investor terlalu tinggi dalam menaksir laba yang sebagai suatu indikator kinerja manajer. Demikian apabila angka laba yang taksir terlalu tinggi yang berakibat menutupi perusahaan dalam hal membayar kewajiban/utangnya yang sebenarnya \& dapat berakibat buruk juga karena dapat menunjukan sautu informasi yang menyesatkan terhadap kreditur untuk melanjtkan memberikan kredit/menangguhkan penyitaan.

Berlandaskan latar belakang yang telah dipaparkan diatas penulis dapat mengajukkan perumusan masalah dibawah ini:

a. Apakah terdapat pengaruh Pengungkapan CSR secara parsial terhadap Manajamen Laba?

b. Apakah terdapat pengaruh Persistensi Laba secara parsial terhadap Manajamen Laba?

c. Apakah ada pengaruhnya Pertumbuhan Laba secara parsial terhadap Manajamen Laba?

\subsection{Tujuan Penelitian}

Sesuai dengan pengajuan rumusan masalah yang dinyatakan diatas berikut tujuannya dibawah ini:

a. Untuk menganalisis pengaruh Pengungkapan CSR secara parsial terhadap Manajamen Laba

b. Untuk menganailisis pengaruh Persistensi Laba secara parsial terhadap Manajamen Laba

c. Untuk menganailisis pengaruh Pertumbuhan Laba secara parsial terhadap Manajamen Laba

\subsection{Teori Agensi}

Diterangkan dalam teori keagenan bahwa perusahaan meruapakan sekumpulan hubungan yang kontrakual, yang mana sebagai hubungan kontrak prinsipal. (pemberi) dan agen. (penerima), (Jensen \& Mackling, .2000) yang fokus-nya kepada hubungan kontraktual antara owner dan manajer. Pada teori agensi sebagai pemilik yang mendelegasikan wewenang untuk mengelola perusahaan oleh manajer dari situ manajer mendapatkan imbalan atas kinerjanya. Hal demikian dapat memberi keleluasaan bagi manajer untuk memanipulasi kinerja ekonomi perusahaan dengan menyesatkan informasi laporan keuangan serta kinerja perusahaan kepada pemilik perusahaan. Oleh sebab itu Setiap tindakan yang dialakukan manajemen yang tentu dapat mempengaruhi angka laba yang dilaporkan untuk tujuan tertentu yaitu adalah Manajemen Laba.

Selisih antara laba buku dengan kas adalah definisi dari akrual, (Kustinah, 2011).

Timbulnya akrual dikarenakan metode-metode akuntasi berupa cadangan kerugian, depresiasi, dan sebagainya. Didalam riset akuntansi semua akrual yang timbul pada satu periode jangka waktu tertetu ialah Total Akrual. Nondiskresioner dan diskresioner merupakan 2 bagian dari Total Akrual. Yang dimaksud akrual diskresioner yaitu akrual yang tidak kedapatan mempunyai hubungan langsung dengan fenomena ekonomi perusahaan \& yang timbul berdasarkan kebijakan dari manajemen saja. Sedangkan bagian ke 2 total akrual yaitu akrual nondiskresioner yang dapat dijelaskan variasi-nya dapat dijelaskan oleh variasi fenomena ekonomik perusahaan.

\subsection{Pengungkapan CSR}

Pengungkapan CSR didalam pnelitian ini dapat diproksikan menggunakan CSRI (Corporate Social Responsibility) yang mengacu pada pedoman instrumen GRI (Global Instrument Initiative) menggunakan GRI-G4 sebagai versi-nya, yang mempunyai item-item yang total kesulurahan itemnya adalah 91. Untuk mendapatkan hasil nilai keseluruhan skor perhitungan CSR dapat dilakukan dengan memakai pendekatan dikotomi yaitu adalah setiap pengungkapan yang ungkap perusahaan di laporan CSR-nya jika perushaaan mengungkapkan dikasih skor 1, jika tidak mengungkapkan diberi skor (Santi, D. K., \& Wardani, D. K). Untuk memproksikan 
pengungkapan CSR dapat dilakukan dengan rumus berikut ini:

$$
\text { CSRIy }=\frac{\sum X k y}{N y}
$$

Keterangan:

CSRIy : Corpoorate Social Responsibility Index perusahaan y.

$\sum$ Xky $:$ Total dari $1=$ informasi diungkapkan dalam laporan tahunan, $0=$ informasi yang tidak diungkapkan

Ny : Jumlah item perusahaan tahun y

$\mathrm{H}_{1}=$ Pengungkapan CSR memiliki pengaruh signifikan terhadap manajemen laba.

\subsection{Persistensi Laba}

Untuk mengukur persistensi laba dalam penelitian ini penulis menggunakan rumus menurut Persada (2010) dalam Salsabila, Pratomo, dan Nurbaiti (2016) yaitu dengan cara EBT pada tahun sebelumnya diselisihkan dengan laba EBT pada tahun. sekarang, kemudian dibagi dengan total asset. Berikut rumus persistensi laba:

$\mathrm{PRST}=\underline{\mathrm{EBT} \mathrm{t}-1-\mathrm{EBT} \mathrm{t}}$

Total Aset

$\mathrm{H}_{2=}$ Persistensi laba memiliki pengaruh signifikan terhadap manajemen laba.

\subsection{Pertumbuhan Laba}

Laba rugi mendeskripsikan perbandingan antara pendapataan dengan beban-beban. Dilakukan penyajian laba melalui laporan tersebut yang menjadi fokus kinerja perusahaan yang penting. Pertumbuhan laba adalah salah satu ukuran untuk pdapat menilai suatu kinerja didalam suatu perusahaan. Untuk menghitung nilai pertumbuhan laba dapat diproksikan dengan cara laba neto tahun sekarang diselisihkan pada laba bersih pada tahun sebelumnya (Warsidi \& Pramuka, 2000).

$\mathrm{PL}=\underline{\text { Laba bersih tahun } \mathrm{t}-\text { Laba bersih tahun } \mathrm{t}-1}$ Laba bersih tahun $\mathrm{t}-1$

$\mathrm{H}_{3}=$ Pertumbuhan laba memiliki pengaruh signifikan terhadap manajemen laba.

\subsection{Manajemen Laba}

Setiap tindakan yang dialakukan manajemen yang tentu dapat mempengaruhi angka laba yang dilaporkan untuk tujuan tertentu yaitu adalah Manajemen Laba. Setiawati (2002) menyatakan bahwa dengan bermaksud menguntungkan diri sendiri
(Manajer) manajemen laba dpat dilakukan oleh perlakuan manajer terhadap proses melaporkan laporan keuangan terhadap pihak luar (eksternal). Pada penelitian ini manajemen laba diproksikan dengan mengacu pada Model Modifikasi Jones (1995) yaitu dengan cara mencari hasil daripada total akrualnya (TAC) laba bersih pada tahun $\mathrm{t}$ (sekarang) diselisihkan terhadap aruskas aktivitas operasional total pada tahun $\mathrm{t}$ (sekarang).

$$
T A C=\text { NIit }- \text { CFOit }
$$

Memproyeksikan total akrual (TAC) menggunakan Ordinary Leas Square (OLS) untuk memperoleh hasi daripada kofisien regresi. Dapat diejalaskan dengan penjabaran dibawah ini:

$$
\frac{T A_{t t}}{A_{t t-1}}=\beta_{1}\left(\frac{1}{A_{t t-1}}\right)+\beta_{2}\left(\frac{\Delta R e v_{t t}}{A_{t t-1}}\right)+\beta_{3}\left(\frac{P E_{t t}}{A_{t t-1}}\right)+\varepsilon
$$

Jika hasil koefisien regresi sudah dihitung, setelahnya maka dilakukan untuk mencari nondiscretionary accruals (NDA). Berikut rumusnya dapat dijelaskan dibawah ini:

$$
N D A_{i t}=\beta_{1}\left(\frac{1}{A_{i t-1}}\right)+\beta_{2}\left(\frac{\Delta R e v_{i t}}{A_{i t-1}}-\frac{\Delta \operatorname{Rec}_{i t}}{A_{i t-1}}\right)+\beta_{3}\left(\frac{\mathrm{PPE}_{i t}}{A_{i t-1}}\right)
$$

Setelah memperoleh nilai nondiscretionary accruals (NDA). Selanjutnya adalah mencari distrectionary accruals (DA) yang sebagai ukuran daipada manajemen laba dengan membandingkan total akrual dengan total aset tahun sebelum-nya hasil nya diselisihkan dengan hasil NDA-nya berikut penjabarannya:

$$
D A_{i t}=\frac{T A_{i t}}{A_{i t-1}}-N D A_{i t}
$$

\section{Keterangan:}

DAit. = Discretionary Accruals padap perusahaan I dalam tahun $\mathrm{t}$

NDAit. = Nondistrectionary Accruals perusahaan $\mathrm{i}$ Pada tahun $\mathrm{t}$

TAit. = Toal Aruals perusahaan i pada tahun $\mathrm{t}$

NIit. = Laba bersih perusahaan i pada tahun $\mathrm{t}$

CFOit. = Arus kas dari aktivitas operasi Perusahaan i pada tahun $\mathrm{t}$

Ait-1. = Total asset perusahaan i pada tahun $\mathrm{t}$

$\Delta$ ReVit. $=$ Pendapatan perusahan i pada tahun $\mathrm{t}$ Diselisihkan dengan Pendapatan Perusahaan i pada tahun t-1

$\Delta$ Recit. = Piutang usaha perusahaan i pada tahun $\mathrm{t}$ Diselisihkan dengan Piutang usaha Perusahaan i pada tahun t-1

PPEit. = Total asse tetap berwujud perusahaan $\mathrm{i}$ Pada tahun $\mathrm{t}$

$\varepsilon . \quad=$ Standard Error

$\mathrm{H}_{4}=$ Pengungkapan CSR, persistensi laba, \& pertumbuhan laba memiliki pengatuh signifikan terhadap manajemen laba. 


\subsection{Penelitian Terdahulu}

Berikut penelitian terdahulu yang berkaitan dengan variable-variabel dalam penelitian ini:

\begin{tabular}{|c|c|c|}
\hline PENELITI & \begin{tabular}{|c|} 
JUDUL \\
PENELITIAN
\end{tabular} & $\begin{array}{c}\text { HASIL } \\
\text { PENELITIAN }\end{array}$ \\
\hline $\begin{array}{l}\text { Herni, Y. } \\
\text { A. } \\
(2019) .\end{array}$ & $\begin{array}{l}\text { Pengaruh } \\
\text { rasio } \\
\text { keuangan } \\
\text { terhadap } \\
\text { pertumbuhan } \\
\text { laba pada } \\
\text { Perusahaan } \\
\text { asuransi yang } \\
\text { Listing di } \\
\text { BEI }\end{array}$ & $\begin{array}{l}\text { Diperoleh hasil dari uji } \mathrm{F} \\
\text { secara simultan yg } \\
\text { menyatakan bahwa } \\
\text { variable independen } \\
\text { (DER,ROI) berpengaruh } \\
\text { secara signifikan terhadap } \\
\text { variabel dependen } \\
\text { (pertumbuhan laba). } \\
\text { Uji t } \\
\text { menunjukkan } \\
\text { Bahwa variabel Debt to } \\
\text { Equity } \\
\text { Ratio berpengaruh positif } \\
\text { yang tidak signifikan } \\
\text { terhadap pertumbuhan } \\
\text { laba, } \\
\text { sedangkan } \\
\text { Return on variabel } \\
\text { Investmen berpengaruh } \\
\text { positif yang tidak } \\
\text { signifikan } \\
\text { terhadap pertumbuhan } \\
\text { laba. }\end{array}$ \\
\hline $\begin{array}{l}\text { Santi, D. } \\
\text { K., \& } \\
\text { Wardani, } \\
\text { D. K. } \\
\text { (2018). }\end{array}$ & $\begin{array}{l}\text { Pengaruh Tax } \\
\text { Planning, } \\
\text { Ukuran } \\
\text { Perusahaan, } \\
\text { Corporate } \\
\text { Social } \\
\text { Responsibilit } \\
\text { y (CSR) } \\
\text { Terhadap } \\
\text { Manajemen } \\
\text { Laba. }\end{array}$ & $\begin{array}{l}\text { Tax planning ada } \\
\text { pengaruh nya kepada } \\
\text { manajemen laba. Dari } \\
\text { hasil uji t secara parsial } \\
1.449 \text { lebih kecil ari } 1.688 \\
\text { \& nilai signifikannya } \\
0.156 \text { lebih besar dari } \\
0.05 \\
\text { Maka H0 diterima \& H1 } \\
\text { Ditolak } \\
\text { Pengaruh negatifnya } \\
\text { ukuran perusahaan } \\
\text { terhadap manajemen laba, } \\
\text { dari uji t hitung di angka - } \\
\text { 7.853 \& tingkat } \\
\text { signifikannya } 0.000 . \\
\text { maka H2 dapat diterima } \\
\text { Ada pengaruh positif } \\
\text { CSR terhadap manajemn }\end{array}$ \\
\hline
\end{tabular}

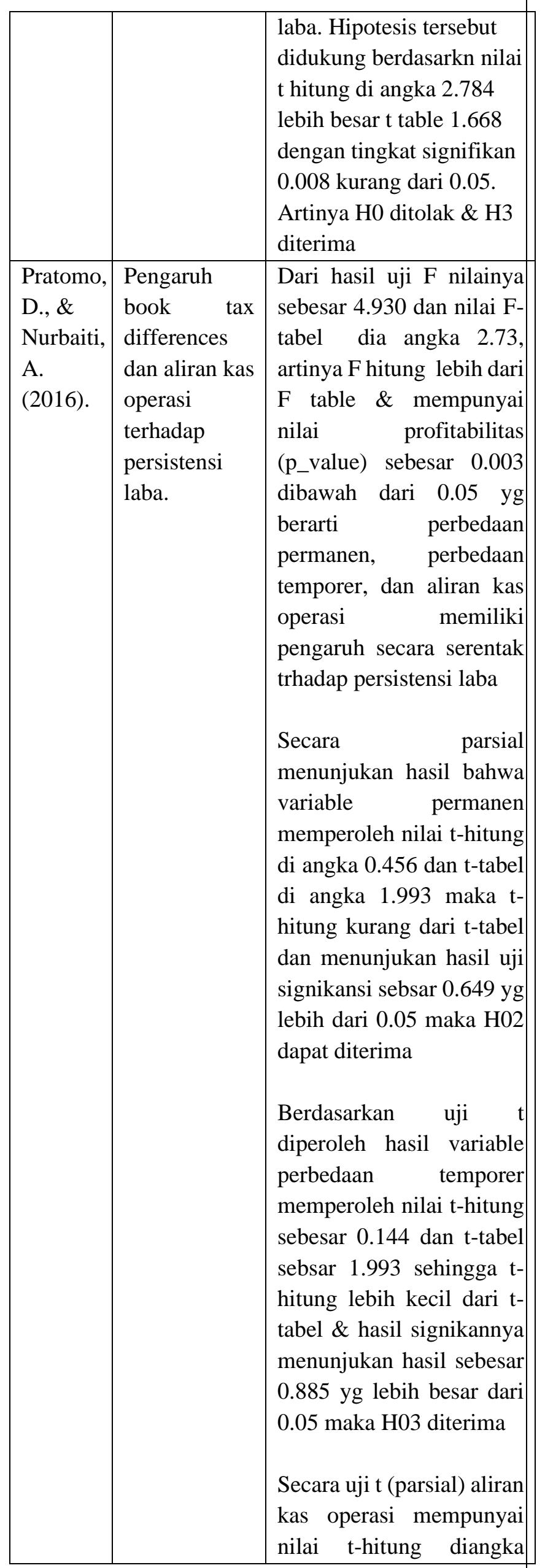




\begin{tabular}{|l|l|}
\hline & $\begin{array}{l}3.666 \text { dan t-tabel sebsar } \\
1.993 \text { sehnga t-hitung } \\
\text { lebih besar dari t-tabel dan } \\
\text { hasil uji signikannya } \\
\text { diperoleh hasil 0.00 yg } \\
\text { lebih kecil dari 0.05 maka } \\
\text { H04 ditolak \& HA4 } \\
\text { diterima }\end{array}$ \\
\hline
\end{tabular}

\subsection{Metodologi Penelitian}

\section{Populasi dan Sampel}

Penelitian ini menggunakan data sekunder berupa laporan tahunan dan laporan keuangan yang diterbitkan oleh perusahaan yang terdaftar di Jakarta Islamic Index (JII) pada Bursa Efek Indonesia periode 2015-2018. Adapun data tersebut diperoleh dari melalui akses website masing-masing perusahaan yang terdaftar di JII dan www.idnfinancials.com. Populasi dalam penelitian ini adalah perusahaan yang terdaftar di JII pada Bursa Efek Indonesia berjumlah 30 perusahaan. Pemilihan sampel menggunakan teknik purposive sampling. Kriteria sampel dalam penelitian ini yaitu:

a. Perusahaan yang konsisten menerbikan Laporan Tahunan-nya pada tahun 2015-2018

b. Perusahaan yang lengkap menerbitkan Laporan Keuangan-nya pada tahun 2015-2018

c. Perusahaan yang menggunakan mata uang rupiah (Rp)

\section{PEMBAHASAN}

Penelitian ini menggunakan perusahaan publik yang terdaftar sahamnya di Jakarta Islamic Index dan BEI periode 2015-2018. Dari kriteria purposive sampling, dapat diperoleh 11 sampel (perusahaan yg terdaftar di JII). Penelitian ini dialkukan selama periode (2015-2018) 4 tahun sehingga total sampel penelitian ini adalah 44 data. Dapat dilihat dari Tabel 1 untul proses pengambilan sampel.

\subsection{Analisis Statistik Deskriptif}

Dari data tabel 1.2, dapat memperlihatkan hasil uji statistic descriptive terhadap manajemen.laba yang menunjukan bahwa manajemen laba (variabel Y) diperoleh rata-rata 0,15864 . Manajemen Laba mempunyai nilai minimum sebesar $-0,157$ dan Nilai Maksimum sebesar 0,1380 yang berarti nilai manajemen laba pertahun pada sampel yang diteliti cukup besar apabila dilihat dari nilai maximum dan minimumnya. Nilai standar deviasi adalah 0,536455 (lebih besar dari mean) menunjukkan data yang cukup bervariasi.

Variabel Pengungkapan CSR mempunyai nilai mean di-angka 0,235500. Hal ini menunjukan bahwa setiap perusahaan memiliki rata-rata Pengungkapan CSR $23,55 \%$. Nilai minimumnya 0,0660 atau $6,6 \%$ dan maksimum nya 0,4620 atau $46,2 \%$. Nilai dari standar deviasi adalah 0.1304414 (lebih kecil dari mean) menunjukkan data yang kurang bervariasi.

Variabel X2 (Persistensi Laba) memiliki nilai minimum-nya di-angka $-0,990$ serta memiliki nilai maksimum-nya pada angka 0,0640. Dari tebel diatas nilai mean lebih kecil dari standar deviasinya maka terjadi penyimpangan pada variabel persistensi laba. Dimana nilai mean harus lebih besar dari standar deviasi agar tidak terjadi penyimpangan.

Variabel X3 (Pertumbuhan Laba) memiliki nilai mean di-angka 0,101864 artinya terhadap sampel perusahaan rata-rata memiliki nilai pertumbuhan laba pada angka $10,1664 \%$. Nilai minimun $-0,05190$ dan maksimum 0,8280. standar dviasi 0,2854546 (lebih besar dari mean) menunjukan simpangan data yang relative besar, karena nilainya yang lebih besar dari nilai mean-nya.

\subsection{Uji Regresi Linear Berganda}

Dari hasil Tabel 3. Lampiran Coefficients tersebut, berikut adalah persamaan regresi dari hasil table 3 di lampiran.

$\mathbf{Y}=0,011-0,053$ CSR + -0,595 PERST + -0,091 GR

\subsection{Uji Asumsi Klasik}

Dapat dilihat dari tabel 3, yang memperoleh hasil uji multikolinieritas tidak ada satupun terhadap keseluruhan variabel $\mathrm{x}$ dengan nilai nya dibawah 0.10 terhadap tolerance-nya dan melebihi 10 dari pada nilai VIF-nya. Berdasarkan hasil tersebut artinya antara variabel $\mathrm{x}$ terbebad dari masalah multikolinieritas pada model regresi.

\subsection{Uji Parsial (t)}

Dilihat berdasarkan hasil dari tabel 3 dapat diterangkan bahwa:

a. Dari uji t (parsial) variabel Pengungkapan CSR mempunyai nilai signifikassi pada angka 0,398 yaitu lebih besar daripada taraf signikansi 0,05 . Berdasarkan hasil uji hipotesis menunjukan bahwa Pengungkapan CSR tidak ada pengaruh signifikansi-nya terhadap Manajemen Laba. Dan menolak variabel satu $\mathrm{H} 2$ yang menerangkan akan 
Pengungkapan CSR terdapat pengaruh signifikannya terhadap variabel terikat/ independen (Manajemen Laba)

b. Dari pengujian uji $\mathrm{t}$ (parsial) maka dapat diberi kesimpulan bahwa variabel bebas (indepnden) Persistensi Laba mendapati nilai di angka sebesar 0,111 yaitu lebih besar daripada taraf signikansi 0,05. Berdasarkan hasil uji hipotesis menunjukan bahwa Manajemen Laba tidak dapat dipengaruhi dengan signifikan oleh Pengungkapan CSR. Dan menolak variabel ke-dua $\mathrm{H} 3$ yang menduga bahwa Persistensi Laba ada pengaruh signifikansi-nya pada Manajemen Laba.

c. Dari pengujian perhitungan uji t maka dapat diberi kesimpulan bahwa variable bebas (independen) Pertumbuhan Laba mendapati nilai signifikassi di angka diangka 0.027 nilainya dibawah daripada taraf signikansi 0.05. Berdasarkan hasil uji hipotesis menunjukan bahwa Pertumbuhan Laba terdapat pengaruh signifikansi-nya terhadap variabel terikat (independen) Manajemen Laba. Dan menerima variabel ke-tiga $\mathrm{H} 4$ yang menerangkan bahwa terdapat pengaruhnya positif signifikan pada pertumbuhan laba terhadap manajemen laba.

\subsection{Uji_F (Simultan)}

Dapat dilihat dari tabel 1.8, dapat diterangkan akan nilai signifikan-nya oleh hasil uji F (Simultan) di angka 0,089 . Hal ini berarti nilai signifikansi pada uji F kurang dari 0,05 (0,089 > 0,05). Oleh sebab itu H1 tidak deterima Dengan demikian hipotesis yang diajukan penulis ditolak berdasarkan hasil uji $\mathrm{F}$ dalam penelitian ini. Sehingga bisa dinyatakan maka model regresi tersebut yang secara simultan tidak berpengaruh signifikan terhadap Y.

\subsection{Koefisien Determinasi}

a. Diperoleh hasil dari tabel 5 , dapat diperoleh nilai diangka 0,200 atau $20 \%$ pada nilai koefisien determinasi-nya (Adjusted R2). Hal ini menunjukan Pengungkapan CSR, Persistensi Laba, dan Pertumbuhan Laba berkontribusi 20\% terhadap besarnya Manajemen Laba. Sedangkan yang dipengaruhi oleh variabel lain diluar penelitian ini ialah sisa-nya yaitu sebesar $80 \%$.

b. Diperoleh hasil diangka 0.507 pada nilai R-nya yang berarti bahwa tingginya tingkat korelasi bergandanya.

\section{KESIMPULAN}

Berdasarkan penelitian yang telah dilakukan atas variabel pengungkapan CSR, persistensi laba, pertumbuhan laba, terhadap manajemen laba khususnya pada perusahaan yang terdaftar di jakarta Islamic Index selama periode 2015-2018 dapat ditarik kesimpulan sebagai berikut:

1. Pengungkapan Corporate Social Responsibility dan Persistensi Laba pada perusahaan yang telah menerapkan prinsip etis islam terbukti secara empiris terbukti tidak berpengaruh terhadap manajemen laba

2. Sedangkan pertumbuhan laba pada perusahaan yang telah menerapkan prinsip etis islam terbukti secara empiris berpengaruh terhadap manajemen laba.

Saran peneliti disini untuk penelitian selanjutnya adalah untuk menambahkan variabel lain yang dianggap berpengaruh terhadap manajemen laba seperti GCG dan ukuran perusahaan serta dengan menambahkan waktu dan jumlah sampel yang di teliti.

\section{REFERENSI}

Afni, S. M, Ratnawati, D. V., \& Basri, Y. (2014). Pengaruh Persistensi Laba, Alokasi Pajak Antar Periode, Ukuran Perusahaan, Pertumbuhan Laba Dan Profitabilitas Terhadap Kualitas Laba. Jurnal Online Mahasiswa Fakultas Ekonomi, 1(2), $1-21$. https://www.neliti.com/publications/33512/peng aruh-persistensi-laba-alokasi-pajak-antarperiode-ukuran-perusahaan-pertumbu

Francis, Jennifer, and J. D. Hanna. "K. Schipper and L. Vincent. 2003. The relative and incremental explanatory power of earnings and alternative (to earnings) performance measures for returns." Contemporary Accounting Research 20, no. 1: 121-164

Fanani, Z. (2010). Analisis Faktor-Faktor Penentu Persistensi Laba. Jurnal Akuntansi Dan Keuangan Indonesia, 7(1), 109-123. https://doi.org/10.21002/jaki.2010.06

Ghozali, Imam., Chariri, Anis. 2007. Teori Akuntansi Edisi 3. Semarang. Penerbit Universitas Diponegoro

Herni YA (2019). Pengaruh rasio keuangan terhadap pertumbuhan laba pada perusahaan asuransi yang listing di BEI. INA-Rxiv Papers. https://osf.io/preprints/inarxiv/gbjah/ 
Kalbuana, N., Sutadipraja, M. W., Purwanti, T., \& Santoso, D. (2019). Pengungkapan islamic social reporting: pengaruh profitabilitas, leverage, dan kinerja lingkungan (studi empiris pada perusahaan yang terdaftar di JII Tahun 20132017). 2(2), 233-248. https://doi.org/10.21043/aktsar.v2i2.6037

Kustinah, S. (2011), Model pendeteksian manajemen laba dan pengaruhnya terhadap kapital Aset:, Jurnal Akuntansi dan Keuangan 16(2), .

Marietza, F., \& Alfredo, D. Y. (2019). Pengaruh Pengungkapan Corporate Social Responsibility Terhadap Kepemilikan Institusional. Jurnal Akuntansi, 7(2), 71-86. https://doi.org/10.33369/j.akuntansi.7.2.71-86

Pratomo, D., \& Nurbaiti, A. (2016). Pengaruh book tax differences dan aliran kas operasi terhadap persistensi laba. Jurnal Akuntansi, https://doi.org/10.24912/ja.v20i2.61

Mukhtarova, A., \& Smith, A. (2014). Aspiring international standards: Challenges and outcomes of project management in the context of Kazakhstan higher education. Life Science Journal, 11(6), 218-222. https://doi.org/10.5281/zenodo.41771

Setiawati, L. (2002). Manajemen Laba dan IPO di Bursa Efek Jakarta. Simposium Nasional Akuntansi, 5, 112-125.

Silins H., Mulford B. (2002) Leadership and School Results. In: Leithwood K. et al. (eds) Second International Handbook of Educational Leadership and Administration. Springer International Handbooks of Education, vol 8. Springer, Dordrecht

Warsidi \& Pramuka (2000). Pemahaman Ekonomi Umum. PT. Gramedia Pustaka: Jakarta. Winarno, W. W. (2007). Analisis Ekonometrika dan Statistik Dengan Eviews. Yogyakarta: UPP YKPN.

Wibisono, Y. (2007). Membedah Konsep dan Aplikasi Corporate Social Responsibility. Gresik : Facho Publishing

Wahyuni, A., \& Damayanti, C. R. (2020). Pengaruh Persistensi Laba, Struktur Modal dan Corporate Sosial Responsibility (CSR) Terhadap Earning Response Coefficient (ERC). Jurnal Asministrasi Bisnis, 78(1), 38-45.
Salsabila, A., Pratomo, D., \& Nurbaiti, A. (2016). Pengaruh Book Tax Differences. Pengaruh Book Tax Differences Dan Aliran Kas Operasi Terhadap Persistensi Laba, 20(Mei), 314329.https://doi.org/http://dx.doi.org/10.24912/ja. v20i2.61

Santi, D. K., \& Wardani, D. K. (2018). Pengaruh Tax Planning, Ukuran Perusahaan, Corporate Social Responsibility (Csr) Terhadap Manajemen Laba. Jurnal Akuntansi, 6(1), 11-24. https://doi.org/10.24964/ja.v6i1.536

Tinggi, S., \& Ekonomi, I. (2019). Sekolah tinggi ilmu ekonomi "keuangan, perbankan dan pembangunan", padang. 1-12.

http://www.idx.co.id

www.idnfinancials.com

\section{LAMPIRAN}

Tabel 1. Kriteria dalam menseleksi sampel

\begin{tabular}{|l|c|}
\hline \multicolumn{1}{|c|}{ Kriteria } & Jumlah \\
\hline Total perusahaan yang terdafar di (JII) & 30 \\
\hline $\begin{array}{l}\text { Perusahaan yang laporan tahunannya tidak } \\
\text { lengkap di 2015-2018 }\end{array}$ & $(2)$ \\
\hline $\begin{array}{l}\text { Perusahaan yang laporan keuangannya tidak } \\
\text { lengkap di 2015-2018 }\end{array}$ & $(2)$ \\
\hline $\begin{array}{l}\text { Perusahaan yang menggunakan mata uang selai } \\
\text { rupiah (Rp) }\end{array}$ & $(5)$ \\
\hline $\begin{array}{l}\text { Perusahaan yang data-nya tidak berdistribusi } \\
\text { secara normal }\end{array}$ & $(10)$ \\
\hline $\begin{array}{l}\text { Total sampel penelitian selama 2015-2018 (4 } \\
\text { tahun) }\end{array}$ & 11 \\
\hline
\end{tabular}

Tabel 2. Statistik Deskriptif

Descriptive Statistics
\begin{tabular}{|l|c|r|r|}
\hline & \multicolumn{1}{|c|}{ Mean } & Std. Deviation & \multicolumn{1}{c|}{ N } \\
\hline Manajemen Laba & .015864 & .0536455 & 44 \\
Pengungkapan CSR & .235500 & .1304414 & 44 \\
Persistensi Laba & -.003682 & .0306084 & 44 \\
Pertumbuhan Laba & .101864 & .2854546 & 44 \\
\hline
\end{tabular}

Tabel 3. Koefisien

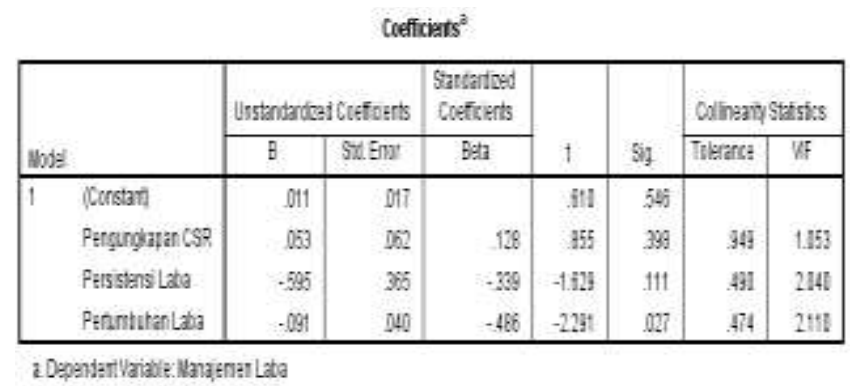


Tabel 4. Uji simultan (Uji F)

\begin{tabular}{|c|c|c|c|c|c|c|}
\hline \multicolumn{7}{|c|}{ ANONA ${ }^{2}$} \\
\hline \multicolumn{2}{|c|}{ Model } & $\begin{array}{l}\text { Sum of } \\
\text { Squares }\end{array}$ & of & Mean Square & $\mathrm{F}$ & $\mathrm{Sig}$ \\
\hline \multirow[t]{3}{*}{1} & Regression & .018 & 3 & .006 & 2.330 & $.089^{b}$ \\
\hline & Residual & .105 & 40 & .003 & & \\
\hline & Total & .124 & 43 & & & \\
\hline
\end{tabular}

a. Dependent Variable: Manajemen Laba

b. Predickus: (Constant, Pertumbuhan Laba, Pengungkapan CSR, Persistensi Laba

Tabel 5. Koefisien determinasi

\begin{tabular}{|l|c|r|r|r|r|}
\hline \multicolumn{1}{|c|}{ Model Summary } \\
\hline Model & $R$ & R Square & $\begin{array}{c}\text { Adjusted R } \\
\text { Square }\end{array}$ & $\begin{array}{c}\text { Sid. Error of } \\
\text { the Estimate }\end{array}$ & $\begin{array}{l}\text { Durbin- } \\
\text { Watson }\end{array}$ \\
\hline 1 & \multicolumn{1}{|c|}{$507^{\mathrm{a}}$} & 257 & .200 & .04399 & 1.722 \\
\hline
\end{tabular}

a. Predictors: (Constant), Lag_X3, Lag_X1, Lag_X2

b. Dependent Variable: Lag_Y

Tabel 6. Korelasi

\begin{tabular}{|c|c|c|c|c|c|}
\hline \multicolumn{6}{|c|}{ Coetelatians } \\
\hline & & $\begin{array}{c}\text { Wanamath } \\
\text { Lasa }\end{array}$ & $\begin{array}{c}\text { Fong̨ungiapa } \\
\text { nCSR }\end{array}$ & $\begin{array}{c}\text { Porsistamil } \\
\text { Lata }\end{array}$ & $\begin{array}{c}\text { Pennivithan } \\
\text { Lata }\end{array}$ \\
\hline \multirow[t]{4}{*}{ Pagros Cartimon } & 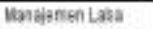 & 9060 & .192 & 023 & .272 \\
\hline & Pengunglayan CSR & 152 & 1900 & 125 & $-2 m$ \\
\hline & Peisist9es Lato & 923 & 128 & 1000 & 513 \\
\hline & Pertumtutian Latis & -272 & -2280 & -713 & 1000 \\
\hline \multirow[t]{4}{*}{$529(1-23)+\infty$} & 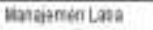 & & 105 & 422 & Dal? \\
\hline & Pengargaran CSR & 105 & & 209 & 075 \\
\hline & Persintansi Lata & 442 & 200 & & 001 \\
\hline & Patumtutan Latha & $38 \pi$ & \$15 & 100 & \\
\hline \multirow[t]{4}{*}{ W } & Vanzagren Las & 4 & 4 & 4 & 44 \\
\hline & Penyungapan CSR & 4 & $\mu$ & 4 & u \\
\hline & Persingansi Lata & 44 & 44 & 4 & 44 \\
\hline & Pentunturan Laba & 44 & 4 & 4 & 4 \\
\hline
\end{tabular}

\begin{tabular}{|c|c|c|c|}
\hline \multicolumn{4}{|c|}{ Variables Entered/Removed ${ }^{a}$} \\
\hline Model & $\begin{array}{c}\text { Variables } \\
\text { Entered }\end{array}$ & $\begin{array}{l}\text { Variables } \\
\text { Removed }\end{array}$ & Method \\
\hline 1 & $\begin{array}{l}\text { Pertumbuhan } \\
\text { Laba, } \\
\text { Pengungkapa } \\
\text { n CSR, } \\
\text { Persistensi } \\
\text { Laba }^{\text {b }}\end{array}$ & & Enter \\
\hline
\end{tabular}

a. Dependent Variable: Manajemen Laba

b. All requested variables entered.

Colnerity diagnostes ${ }^{2}$

\begin{tabular}{|c|c|c|c|c|c|c|c|}
\hline \multirow[b]{2}{*}{ Uodal } & \multirow[b]{2}{*}{ Dimension } & \multirow[b]{2}{*}{ Eiganadue } & \multirow[b]{2}{*}{$\begin{array}{l}\text { Confibus } \\
\text { nder }\end{array}$} & \multicolumn{4}{|c|}{ Veriana Parofuns } \\
\hline & & & & (Corsiart & $\begin{array}{c}\text { Penyungrop } \\
\text { nCS5? }\end{array}$ & $\begin{array}{c}\text { Peristens } \\
\text { Lata }\end{array}$ & $\begin{array}{c}\text { Pestimbilan } \\
\text { Latala }\end{array}$ \\
\hline 1 & 1 & 2188 & 1001 & 93 & 03 & 16 & 16 \\
\hline & 2 & 1.46 & 1225 & 92 & 01 & 13 & in \\
\hline & 2 & 778 & 2791 & at & of & 79 & 73 \\
\hline & 4 & 187 & 4.9? & 95 & 89 & M & 16 \\
\hline
\end{tabular}

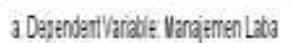

\begin{tabular}{|c|c|c|c|c|c|}
\hline \multicolumn{6}{|c|}{ Residauals Statistics" } \\
\hline & Tinimum & Masimum & Mesn & ज्ञात Deviation & $\bar{N}$ \\
\hline Predicted Vxive & .055168 & 050887 & $0+5864$ & 0206913 & 44 \\
\hline Stil Predicted value & -3.433 & 1002 & 000 & +000 & 44 \\
\hline $\begin{array}{l}\text { Standarit Erroe of } \\
\text { Predicted Value }\end{array}$ & Dot & $03 n$ & 015 & 005 & 44 \\
\hline Aquasted Predicted value & 023181 & 057290 & 017210 & 0196471 & 44 \\
\hline Residual & -1285832 & .1254244 & .0000000 & 0494946 & 44 \\
\hline stid Residual & -2.506 & 2444 & .000 & 964 & 44 \\
\hline stuit Residual & -2.609 & 2.503 & -.013 & +042 & 44 \\
\hline Deleted Residual & -1688386 & 1314973 & -0015483 & 0584270 & 44 \\
\hline Stud Deleled Residual & -2.233 & $259 t$ & -020 & 1.097 & 44 \\
\hline Mana Dostance & 057 & 15057 & 2.932 & 2.821 & 44 \\
\hline Cocks Distance & 000 & 1069 & .051 & 170 & 44 \\
\hline Cartared Leverage Velue & 001 & 323 & 068 & 066 & 44 \\
\hline
\end{tabular}

\section{Gambar 1. Histogram}

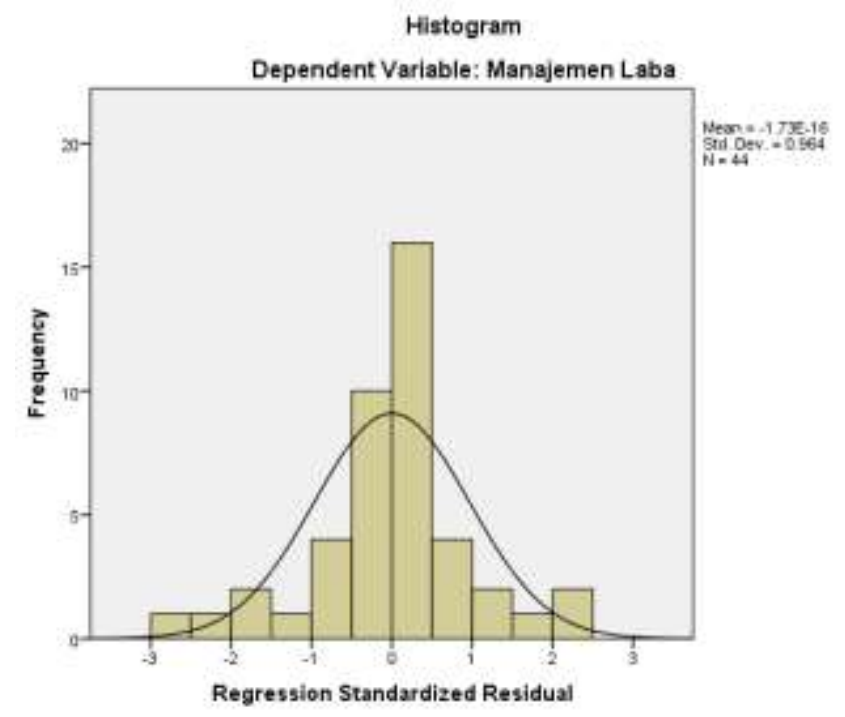

Gambar 2. Normal P-Plot of regression Standardized residual

Normal P.P Plot of Regression Standardized Residual

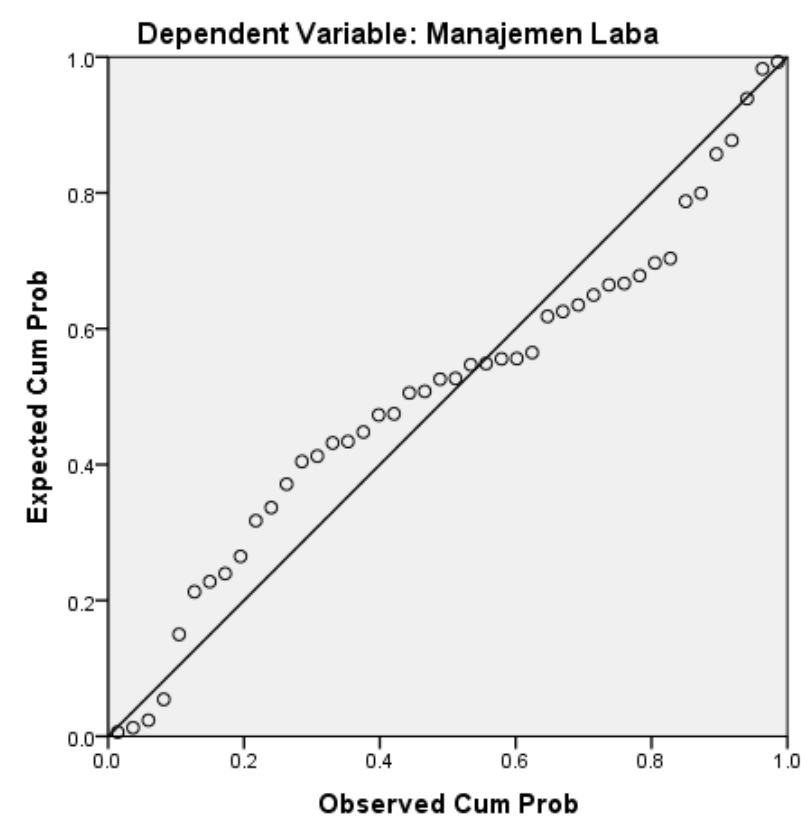


Jurnal Ilmiah Ekonomi Islam, 6(02), 2020, 358

Gambar 3. Scatterplot

Scatterpiot

Dependent Variable: Manajemen Laba

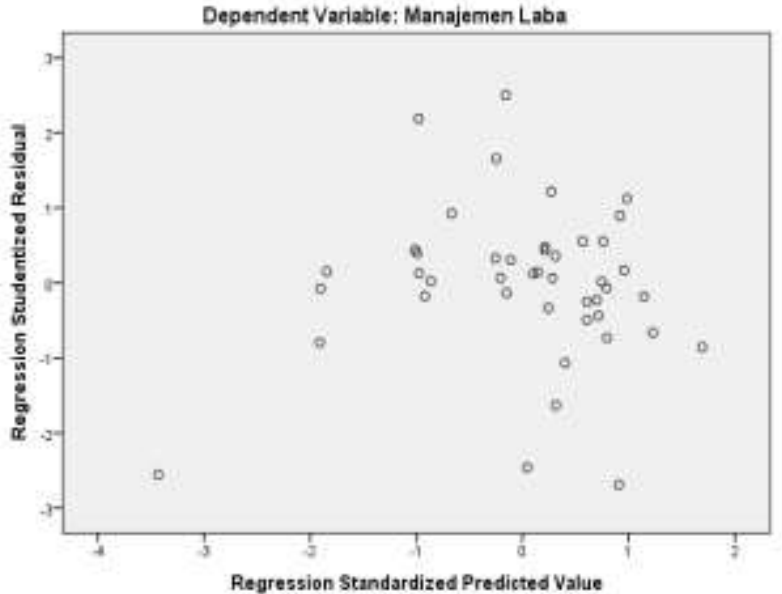

